\title{
The Use of PR Tools and Analysis of Their Effectiveness as Viewed by Managers of Czech Chemical Companies
}

\author{
Martina JELINKOVA*, Hana LOSTAKOVA and Katerina MACHACKOVA \\ University of Pardubice, Pardubice, Czech Republic, martina.jelinkova@upce.cz, hana.lostakova@upce.cz \\ * Correspondence: martina.jelinkova@upce.cz
}

\begin{abstract}
The paper presents the results of primary quantitative research aimed at determining the degree of use of various PR tools and evaluating their perceived effectiveness with the public. The respondents were managers of chemical industrial companies in the Czech Republic. It compares the use and perceived effectiveness of the monitored PR tools and identifies those that should be maintained, those that need to be developed and also those that should be restrained. This provides managers with a suitable guide for effective management of PR communication. The findings are supplemented by an analysis of differences in the use of monitored PR tools by the size of companies and differences in the perception of the effectiveness of the monitored PR tools according to different characteristics of respondents. It was confirmed that PR tools aimed at the public are used to a greater extent by larger companies (more than 250 employees) and respondents' views differ the most in the perceived effectiveness of press releases.
\end{abstract}

Keywords: public relations; PR tools; influencing the public; chemical industry

JEL Classification: L60; M21; M31

\section{Introduction}

Public relations (PR) are a standard part of corporate communication, the aim of which is to create and support effective strategic two-way communication between the company and its surroundings (Meyrs, 2016). Opinions on the definition of PR differ among experts and there are more than five hundred definitions today (Garcia-Nieto et al., 2020). The most frequently cited definition of PR from 1978 by the British Institute of Public Relations, which described PR as "the deliberate, planned and sustained effort to establish and maintain mutual understanding between an organisation and its publics" (Novotna \& Musil, 2017; Kopecky, 2013; Ftorek, 2010). This definition was modified by the PRSA (Public Relations Society of America) in 2011-2012 so that the definition of PR even more respected the role of relationships, mutual respect, and strategic communication: "public relations is a strategic communication process that builds mutually beneficial relationships between organizations and their publics." (Corbett, 2012)

It clearly follows from the definition of PR that an important step in PR management is to precisely define those groups of the public on which their activities will focus. Proper identification of PR target groups is crucial for the company (Musil, 2005) as it predetermines 
the usable PR techniques and tools as well as the type of information communicated. (Destiny, 2018) In the current literature, target groups are often referred to by the collective term "stakeholders". According to Heskova and Starchon (2009), there are two basic groups of stakeholders who require different forms of communication and communication channels and include two basic areas of activity (Kotler \& Keller, 2012; Kotler et al., 2019):

- Internal Public Relations are focused primarily on employees, the goal is to motivate and harmonize them with the culture, interests and strategic goals of the organization.

- External Public Relations are focused on maintaining and improving relationships with key partners, interest groups and the public, their goal is to improve the image of the organization.

Logically, the two groups of PR activities are fundamentally different. However, even within each area of PR, it is possible to trace the variability of using different PR tools according to a specific category of target stakeholders. This is confirmed by research by Sommerfeldt et al. (2019), who also believe that the specificity of the use of different PR tools will depend on the type of company and industry.

Given the focus of our research, we directed our attention on mapping those PR tools that, in the opinion of experts, could be used in external PR specifically towards the general and local public. Many authors deal with these PR tools in various contexts. According to most authors (e.g. Svoboda, 2009; Foret, 2011; Hejlova, 2015; Rubtcova \& Pavenkov, 2019; Solmonova \& Volkonskij, 2019), the most used PR tools aimed at influencing the general and local public include:

- information publicity, such as press releases, press conferences or discussions, annual reports, corporate magazines, bulletins, newsletters, etc.;

- advertising of the organization that is a combination of advertising and public relations and is not focused on a specific product, but on the company as a whole. According to the above-mentioned authors, advertising of the organization can be realized through, for example, websites, billboards, leaflets, posters and media messages promoting only the company and, for example, its social activities, this can also include information published in the media or otherwise published about sponsorship or organizing events, etc.;

- the organization of special events that attract the attention of the selected target group and strengthen its relationship with the brand or organization. According to the abovementioned authors, these events include, for example, social events (concerts, balls, shows, etc.), ceremonial opening of new companies, branches or stores, events for launching new products into the market, open days, etc.;

- sponsorship of cultural, political, sporting or social activities.

Heskova and Starchon (2009) also include media identities in these basic PR tools, which, according to the authors, mainly include company logos and slogans, letterheaded papers, business cards and corporate dress code. Hejlova (2015) also considers the recommendation of celebrities or opinion leaders, or celebrity endorsement, to be an important PR tool that 
has a strong public impact, when a known person's name or face is associated with a certain brand or product, expressing his/her personal support. Last but not least, according to some authors (e.g. Jelinkova et al., 2017; Fawkes, 2018), important PR tools can also include the implementation and presentation of socially responsible activities (CSR), i.e. activities presenting economic, social, environmental and philanthropic corporate responsibility (Tetrevova, 2017; Tetrevova et al., 2019).

From a search of available professional literature, it is clear that there are a number of PR tools recommended for the company's work with the public. Although research by some authors (e.g. Sommerfeldt et al., 2019) suggests that these tools are likely to be used differently with different efficiencies specifically in different industries, there are no studies addressing the feasibility of instruments and monitoring their effectiveness by sector. We therefore tried to close this gap in our research and conducted research comparing the use and effectiveness of various external PR tools specifically in the chemical industry. As part of the research, we monitored all the PR tools listed below (a total of 25 tools) divided into three categories:

- General PR tools: press releases; press conferences; annual reports; corporate newspapers and magazines; bulletins and newsletters; internet presentation of the company; occasional publications; business advertising and identity media.

- PR events: corporate presentation events; thematic conferences or symposia; company days or lectures; company workshops; organization of social events and meetings; organization of events aimed at starting the operation of an entity; open days; organization of charitable (benefit) auctions or events; sponsorship of cultural, political, sports and social events.

- Presentation of social responsibility activities: presentation of information on business activities and economic results; presentation of information on the company's care for employees; presentation of information on the company's care for the environment; presentation of information on the implementation and support of ethical behaviour of your company; presentation of information about the charitable activities of your company.

Our goal was to contribute to the management of effective corporate communication and to identify those PR tools on which companies should focus their attention and increase their use or maintain their level as they appear to be very effective with the public and to specify those PR tools the use of which in relation to the public should be reduced, not developed or innovated in such a way as to increase their impact on the public. We were also interested in whether the use of the given PR tools differs depending on the size of the company and whether opinions on the impact of PR tools on the public differ depending on the different characteristics of the respondents.

\section{Methodology}

Due to the unfavourable epidemiological situation, an electronic survey using an interactive online questionnaire was chosen as the method of primary quantitative research. 
Employees of chemical industrial companies associated in the Association of Chemical Industry of the Czech Republic were addressed, namely product managers, employees of marketing and sales departments and employees of the press department or PR. Respondents were selected by deliberate judgment. The database of contacts was created on the basis of an analysis of the websites of companies associated in the Association of Chemical Industry of the Czech Republic and personal contacts. 53 completely completed questionnaires were obtained. The return on research was about $20 \%$.

The research verified, among other things, the following hypotheses:

H1: Due to their tradition, general PR tools (see above) will be widely used by companies, but if they are not online, they will be ineffective with the public.

H2: PR events will be less used due to their high financial demands and also less effective from the point of view of companies in influencing the public.

H3: The implementation and presentation of socially responsible activities will be widely used for its modernity and also, from the point of view of the respondents, very effective with respect to the public.

H4: Larger companies use PR activities towards the public to a greater extent than small companies.

H5: Older and more experienced employees will have more confidence in more traditional PR tools.

The hypotheses were verified on the basis of the obtained results, which were statistically processed using the IBM SPSS Statistics software platform and are presented below.

\section{Research Results}

The research can be divided into two parts. In the first part of the questionnaire, the level of use of the above-specified PR tools in the addressed companies was determined. A scale of 1-3 was used for the evaluation, where $1=$ not used at all, 2 = partially used, $3=$ fully used. The second phase of the survey concerned the findings of the impact of the given PR tools on the public as perceived by the respondents. The respondents used a scale of $1-4$, where $1=$ no influence, 2 = rather minor influence, 3 = rather greater influence, $4=$ major influence.

The rate of use and the perceived impact of various PR tools on the public were analysed on the basis of the relative frequencies of respondents' responses, the median and the average ranking. The Friedman test at a significance level of 0.05 was used to determine whether the rate of use and the perceived impact on the public were statistically different for different PR tools. Due to the small size of the sample, this test was also suitable owing to the verbal rating scale. In all cases tested, the Friedman test showed a significance of less than 0.05. It can therefore be stated that the level of use of PR tools and their perceived impact on the public differ statistically significantly in all monitored cases.

\section{Comparison of the degree of use and perceived effectiveness of the monitored PR tools with the public}

The analysis of research results and a comparison of the rate of use and perceived effectiveness allowed us to identify four categories of PR tools: 
- The most used and, at the same time, the most effective PR tools in relation to the public (see Table 1).

- Widely used but ineffective (or insufficiently effective) PR tools in relation to the public (see Table 2).

- Little-used but highly effective PR tools in relation to the public (see Table 3).

- Little-used and, at the same time, insufficiently effective PR tools in relation to the public (see Table 4).

We managed to include a total of 13 examined PR tools in these categories; the remaining 12 were in the area of average usage or average efficiency, and therefore it was not possible to categorize them. The specific order of effectiveness and use of the monitored tools has already been published by the authors of the paper, see Jelínková, Loštáková, and Macháčková (2020).

Table 1. The most used and, at the same time, the most effective PR tools in relation to the public

\begin{tabular}{|c|c|c|c|c|c|c|c|c|c|c|c|}
\hline \multirow{3}{*}{ PR tools analysed } & \multicolumn{5}{|c|}{$\begin{array}{l}\text { Rate of use of PR tools according to } \\
\left.\text { respondents }{ }^{*}\right)\end{array}$} & \multicolumn{6}{|c|}{$\begin{array}{l}\text { Influence of PR tools on the public } \\
\text { according to respondents }{ }^{* *} \text { ) }\end{array}$} \\
\hline & \multicolumn{3}{|c|}{$\begin{array}{c}\text { Relative response } \\
\text { rates }(\%)\end{array}$} & \multirow{2}{*}{ 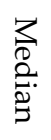 } & \multirow{2}{*}{$\begin{array}{l}\text { Average } \\
\text { ranking }\end{array}$} & \multicolumn{4}{|c|}{$\begin{array}{c}\text { Relative response rates } \\
(\%)\end{array}$} & \multirow{2}{*}{ 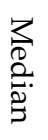 } & \multirow{2}{*}{$\begin{array}{l}\text { Average } \\
\text { ranking }\end{array}$} \\
\hline & 1 & 2 & 3 & & & 1 & 2 & 3 & 4 & & \\
\hline $\begin{array}{l}\text { Internet presentation of the } \\
\text { company }\end{array}$ & 2 & 51 & 47 & 2 & 17.07 & 8 & 20 & 47 & 25 & 3 & 16.15 \\
\hline Sponsorship of sports events & 13 & 51 & 36 & 2 & 15.22 & 5 & 23 & 40 & 32 & 3 & 16.51 \\
\hline $\begin{array}{l}\text { Implementation and } \\
\text { presentation of information } \\
\text { about the company's care for } \\
\text { the environment }\end{array}$ & 19 & 46 & 35 & 2 & 14.68 & 0 & 15 & 47 & 38 & 3 & 19.38 \\
\hline
\end{tabular}

* The scale 1-3 is used, where $1=$ not used at all, 2 = partially used, $3=$ fully used

** The scale 1-4 used, where 1 = no influence, 2 = rather minor influence, 3 = rather greater influence, $4=$ major influence

Table 2. Widely used but ineffective (or insufficiently effective) PR tools in relation to the public

\begin{tabular}{|c|c|c|c|c|c|c|c|c|c|c|c|}
\hline \multirow{3}{*}{ PR tools analysed } & \multicolumn{5}{|c|}{$\begin{array}{l}\text { Rate of use of PR tools according to } \\
\text { respondents }{ }^{*} \text { ) }\end{array}$} & \multicolumn{6}{|c|}{$\begin{array}{l}\text { Influence of PR tools on the public } \\
\text { according to respondents }{ }^{* *} \text { ) }\end{array}$} \\
\hline & \multicolumn{3}{|c|}{$\begin{array}{c}\text { Relative response } \\
\text { rates }(\%)\end{array}$} & \multirow{2}{*}{$\begin{array}{l}\frac{3}{8} \\
\stackrel{2}{0} \\
\tilde{J}\end{array}$} & \multirow{2}{*}{$\begin{array}{l}\text { Average } \\
\text { ranking }\end{array}$} & \multicolumn{4}{|c|}{$\begin{array}{c}\text { Relative response rates } \\
(\%)\end{array}$} & \multirow{2}{*}{$\begin{array}{l}3 \\
\frac{2}{2} \\
0 \\
0 \\
0\end{array}$} & \multirow{2}{*}{$\begin{array}{l}\text { Average } \\
\text { ranking }\end{array}$} \\
\hline & 1 & 2 & 3 & & & 1 & 2 & 3 & 4 & & \\
\hline Annual reports & 26 & 25 & 49 & 2 & 15.10 & 17 & 49 & 25 & 9 & 2 & 10.35 \\
\hline $\begin{array}{c}\text { Corporate newspapers and } \\
\text { magazines }\end{array}$ & 28 & 30 & 42 & 2 & 14.62 & 15 & 32 & 42 & 11 & 3 & 12.76 \\
\hline Occasional publications & 26 & 34 & 40 & 2 & 14.28 & 16 & 45 & 28 & 11 & 2 & 11.04 \\
\hline
\end{tabular}

* The scale 1-3 is used, where $1=$ not used at all, 2 = partially used, $3=$ fully used

** The scale 1-4 used, where 1 = no influence, 2 = rather minor influence, 3 = rather greater influence, $4=$ major influence

The PR tools listed in Table 1 need to be supported and developed using the latest trends, especially those in the field of communication and information technologies. Digital PR, including the company's website, is a modern and rapidly developing area, as is the interest in corporate social responsibility, which also includes corporate environmental 
responsibility. By effectively allocating resources to these PR tools, companies can make the most of their expected effectiveness to the public.

The use of these PR tools, which are probably obsolete with regard to the public, should probably be limited and targeted to other groups of stakeholders. The problem with their usability towards the public is their often-incomplete digitization and transfer to the online environment. Solving this problem could strengthen the impact of these tools on the public. Nevertheless, it seems that the company should not be too active in this category of tools and that it should rather promote tools that are much more effective with the public.

Table 3. Little-used but highly effective PR tools in relation to the public

\begin{tabular}{|c|c|c|c|c|c|c|c|c|c|c|c|}
\hline \multirow{3}{*}{ PR tools analysed } & \multicolumn{5}{|c|}{$\begin{array}{l}\text { Rate of use of PR tools according to } \\
\text { respondents }{ }^{*} \text { ) }\end{array}$} & \multicolumn{6}{|c|}{$\begin{array}{l}\text { Influence of PR tools on the public } \\
\left.\text { according to respondents }{ }^{* *}\right)\end{array}$} \\
\hline & \multicolumn{3}{|c|}{$\begin{array}{l}\text { Relative response } \\
\text { rates }(\%)\end{array}$} & \multirow{2}{*}{ 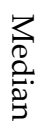 } & \multirow{2}{*}{$\begin{array}{l}\text { Average } \\
\text { ranking }\end{array}$} & \multicolumn{4}{|c|}{$\begin{array}{c}\text { Relative response rates } \\
(\%)\end{array}$} & \multirow{2}{*}{ 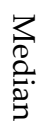 } & \multirow{2}{*}{$\begin{array}{l}\text { Average } \\
\text { ranking }\end{array}$} \\
\hline & 1 & 2 & 3 & & & 1 & 2 & 3 & 4 & & \\
\hline Open days & 30 & 36 & 34 & 2 & 13.43 & 8 & 19 & 33 & 40 & 3 & 18.11 \\
\hline $\begin{array}{c}\text { Creating a quality employee } \\
\text { care system and informing } \\
\text { about it }\end{array}$ & 25 & 50 & 25 & 2 & 13.24 & 6 & 21 & 46 & 27 & 3 & 16.54 \\
\hline $\begin{array}{l}\text { Implementation of charitable } \\
\text { activities of the company. }\end{array}$ & 19 & 58 & 23 & 2 & 13.42 & 4 & 31 & 40 & 25 & 3 & 15.88 \\
\hline
\end{tabular}

* The scale 1-3 is used, where $1=$ not used at all, 2 = partially used, $3=$ fully used

** The scale 1-4 used, where 1 = no influence, 2 = rather minor influence, 3 = rather greater influence, $4=$ major influence

The PR tools listed in Table 3 hide the greatest potential for further development and focus of interest of the PR department of chemical companies. These tools are probably wrongly neglected and more attention needs to be paid to them in the future. It is true that the possibilities for holding open days are limited due to the frequent dangers of chemical plants. Nevertheless, it would be worth considering using this PR tool at least to a limited extent as it would probably be highly appreciated by the public. From the point of view of the quality of the employee care system, the problem is probably not its non-existence, but rather its ineffective communication, which could be easily solved by incorporating appropriate information in the online environment.

Table 4. Little-used and, at the same time, insufficiently effective PR tools in relation to the public

\begin{tabular}{|c|c|c|c|c|c|c|c|c|c|c|c|}
\hline \multirow{3}{*}{ PR tools analysed } & \multicolumn{5}{|c|}{$\begin{array}{l}\text { Rate of use of PR tools according to } \\
\text { respondents *) }\end{array}$} & \multicolumn{6}{|c|}{$\begin{array}{l}\text { Influence of PR tools on the public } \\
\left.\text { according to respondents }{ }^{* *}\right)\end{array}$} \\
\hline & \multicolumn{3}{|c|}{$\begin{array}{c}\text { Relative response } \\
\text { rates }(\%)\end{array}$} & \multirow{2}{*}{$\begin{array}{l}3 \\
\frac{2}{2} \\
0 \\
0 \\
0\end{array}$} & \multirow{2}{*}{$\begin{array}{l}\text { Average } \\
\text { ranking }\end{array}$} & \multicolumn{4}{|c|}{$\begin{array}{c}\text { Relative response rates } \\
(\%)\end{array}$} & \multirow{2}{*}{$\begin{array}{l}3 \\
\frac{2}{2} \\
\stackrel{2}{0} \\
0\end{array}$} & \multirow{2}{*}{$\begin{array}{l}\text { Average } \\
\text { ranking }\end{array}$} \\
\hline & 1 & 2 & 3 & & & 1 & 2 & 3 & 4 & & \\
\hline Identity media & 38 & 36 & 36 & 2 & 11.96 & 21 & 34 & 30 & 15 & 2 & 11.42 \\
\hline Bulletins, newsletters & 45 & 40 & 15 & 2 & 9.96 & 21 & 49 & 26 & 4 & 2 & 9.18 \\
\hline Press conferences & 49 & 42 & 9 & 2 & 9.09 & 15 & 45 & 29 & 11 & 2 & 11.16 \\
\hline Sponsorship of political events & 72 & 21 & 8 & 1 & 7.14 & 43 & 27 & 21 & 9 & 2 & 8.52 \\
\hline
\end{tabular}

* The scale 1-3 is used, where $1=$ not used at all, 2 = partially used, $3=$ fully used

** The scale 1-4 used, where $1=$ no influence, 2 = rather minor influence, 3 = rather greater influence, $4=$ major influence 
In the opinion of the interviewed managers, the low rate of use of these tools is justified due to their low effectiveness and any effort to develop these PR tools seems ineffective in relation to the public.

\section{Analysis of differences in the use and effectiveness of PR tools depending on the characteristics of companies and respondents}

When processing the research results, attention was also paid to the analysis of differences in the use of researched PR tools according to different characteristics of the company and analysis of differences in the perceived impact of each PR tool on the public depending on different characteristics of respondents. Differences were verified using the Kruskal-Wallis test at the 5\% level of significance. The following tables present the results only for those PR tools for which any statistically significant differences were found, i.e. where the significance was less than 0.05 .

The most statistically significant differences were demonstrated in the level of use of various PR tools depending on the size of the company. The results are shown in Table 5.

Table 5. Differences in the use of different PR tools by company size

\begin{tabular}{|c|c|c|c|c|}
\hline \multirow{2}{*}{ PR tools } & \multicolumn{2}{|c|}{$\begin{array}{l}\text { Use of PR tools by company } \\
\text { size } \\
\text { (average ranking) }^{*} \text { ) }\end{array}$} & \multicolumn{2}{|c|}{ Kruskal-Wallis test } \\
\hline & $\begin{array}{c}\text { Small and } \\
\text { medium-sized } \\
\text { enterprises }\end{array}$ & $\begin{array}{c}\text { Large } \\
\text { enterprises }\end{array}$ & $\chi^{2}$ & Sig. \\
\hline Press releases & 18.40 & 31.56 & 10.826 & 0.001 \\
\hline Press conferences & 20.73 & 30.11 & 5.808 & 0.016 \\
\hline Corporate newspapers and magazines & 14.65 & 33.91 & 22.685 & 0.000 \\
\hline Bulletins, newsletters & 21.30 & 29.75 & 4.547 & 0.033 \\
\hline Identity media & 21.15 & 29.84 & 4.586 & 0.032 \\
\hline Business presentation events & 21.25 & 29.78 & 4.778 & 0.029 \\
\hline Thematic conferences or symposia & 20.30 & 30.38 & 6.210 & 0.013 \\
\hline Company days or lectures, workshops & 18.20 & 31.69 & 11.415 & 0.001 \\
\hline Open days & 18.35 & 31.59 & 10.608 & 0.001 \\
\hline Sponsorship of cultural events & 19.75 & 30.72 & 7.580 & 0.006 \\
\hline Sponsorship of sports events & 20.58 & 30.20 & 6.028 & 0.014 \\
\hline Sponsorship of social events & 20.78 & 30.08 & 5.453 & 0.020 \\
\hline $\begin{array}{l}\text { Presentation of information about the company's } \\
\text { care for employees }\end{array}$ & 19.23 & 31.05 & 8.997 & 0.003 \\
\hline $\begin{array}{l}\text { Presentation of information about the company's } \\
\text { care for the environment }\end{array}$ & 18.85 & 31.28 & 9.704 & 0.002 \\
\hline $\begin{array}{c}\text { Presentation of information on the implementation } \\
\text { and support of ethical business conduct }\end{array}$ & 16.05 & 33.03 & 17.642 & 0.000 \\
\hline $\begin{array}{c}\text { Presentation of information about charitable } \\
\text { activities of the company }\end{array}$ & 18.55 & 31.47 & 11.337 & 0.001 \\
\hline
\end{tabular}

\footnotetext{
* The use was assessed on a scale of 1-3 ( 1 = not used at all, 3 = fully used $)$.
} 
According to this characteristic, a difference in the use of 16 monitored PR tools was found, which is $62 \%$ of all monitored PR tools. In all cases, the tools are used more in larger enterprises (i.e. with more than 250 employees).

Statistically significant differences in the perception of the impact of some PR tools on the public were found depending on the following characteristics of the respondents:

- gender of the respondent (see Table 6),

- age of the respondent (see Table 7),

- educational attainment of the respondent (see Table 8),

- level of management at which the respondent is employed (see Table 9).

Table 6. Differences in the perception of the impact of PR tools on the public by gender of the respondent

\begin{tabular}{|c|c|c|c|c|}
\hline \multirow{2}{*}{ PR tools } & \multicolumn{2}{|c|}{$\begin{array}{c}\text { Impact of PR tools by gender of } \\
\text { respondents } \\
\text { (average ranking) }\end{array}$} & \multicolumn{2}{|c|}{ Kruskal-Wallis test } \\
\cline { 2 - 5 } & Men & Women & $\chi 2$ & Sig. \\
\hline Internet presentation of the company & 25.23 & 38.40 & 3.948 & 0.047 \\
\hline
\end{tabular}

* Perception was assessed on a scale of 1-4 (1= no impact, $4=$ major impact)

Table 6 shows that the company's internet presentation, which is a frequently used PR tool, is perceived by women as more effective than men. This interesting fact would probably deserve a deeper analysis.

Table 7. Differences in the perception of the impact of PR tools on the public by age of the respondent

\begin{tabular}{|c|c|c|c|c|}
\hline \multirow[t]{2}{*}{ PR tools } & \multicolumn{2}{|c|}{$\begin{array}{l}\text { Impact of PR tools by age of } \\
\text { respondents } \\
\left.\text { (average ranking) }^{*}\right)\end{array}$} & \multicolumn{2}{|c|}{ Kruskal-Wallis test } \\
\hline & Up to 45 years & Over 45 years & $\chi^{2}$ & Sig. \\
\hline Press releases & 20.68 & 28.52 & 4.059 & 0.044 \\
\hline
\end{tabular}

* Perception was assessed on a scale of 1-4 (1= no impact, $4=$ major impact $)$

Table 7 shows that when analysing the differences in the perception of the impact of PR tools on the public by age of the respondent, a statistically significant difference was found only in press releases. Older respondents (over 45 years) perceive this tool as more effective with the public. This may be a reflection of a certain conservatism, where older employees may have more confidence in this traditional PR tool as they consider it to be tried and tested over the years.

Table 8 shows that statistically significant differences depending on the respondent's educational attainment were demonstrated for 4 PR tools. According to university-educated respondents, all of these groups of $\mathrm{PR}$ tools have a greater impact on the public than respondents with lower education believe. It is possible that more educated employees assume a greater desire of the public for information and therefore a greater interest of the public in the above-mentioned PR tools. 
Table 8. Differences in the perception of the impact of PR tools on the public by educational attainment of the respondent

\begin{tabular}{|c|c|c|c|c|}
\hline \multirow{2}{*}{ PR tools } & \multicolumn{2}{|c|}{$\begin{array}{c}\text { Impact of PR tools by educational } \\
\text { attainment of respondents } \\
\text { (average ranking) }\end{array}$} & \multicolumn{2}{|c|}{ Kruskal-Wallis test } \\
\cline { 2 - 5 } & $\begin{array}{c}\text { Secondary education } \\
\text { with exit exam }\end{array}$ & $\begin{array}{c}\text { University } \\
\text { education }\end{array}$ & $\chi 2$ & Sig. \\
\hline Corporate newspapers and magazines & 18.88 & 28.79 & 4.459 & 0.035 \\
\hline Thematic conferences or symposia & 18.42 & 28.93 & 4.949 & 0.026 \\
\hline $\begin{array}{c}\text { Events aimed at starting the operation of a } \\
\text { particular entity or its branch }\end{array}$ & 16.13 & 29.61 & 8.022 & 0.005 \\
\hline Open days & 17.75 & 29.13 & 5.872 & 0.015 \\
\hline
\end{tabular}

* Perception was assessed on a scale of 1-4 (1 = no impact, $4=$ major impact), Source: (Authors)

Table 9 shows that respondents working at a higher level of management believe that press releases and press conferences have a greater impact on the public than that estimated by those from lower levels of management.

Table 9. Differences in the perception of the impact of PR tools on the public by level of management

\begin{tabular}{|c|c|c|c|c|}
\hline \multirow{2}{*}{ PR tools } & \multicolumn{2}{|c|}{$\begin{array}{c}\text { Influence of PR tools by level of } \\
\text { management } \\
\text { (average ranking) }{ }^{*} \text { ) }\end{array}$} & \multicolumn{2}{|c|}{ Kruskal-Wallis test } \\
\cline { 2 - 5 } & $\begin{array}{c}\text { Higher level of } \\
\text { management }\end{array}$ & $\begin{array}{c}\text { Lower level of } \\
\text { management }\end{array}$ & $\chi^{2}$ & Sig. \\
\hline Press releases & 29.08 & 20.13 & 4.139 & 0.042 \\
\hline Press conferences & 29.04 & 20.23 & 4.124 & 0.042 \\
\hline
\end{tabular}

* Perception was assessed on a scale of 1-4 (1= no impact, $4=$ major impact $)$

\section{Discussion}

The use of various PR tools in corporate communication is a traditional way the company influences the public so as to improve the image of the company in its eyes. Today, companies have a plethora of opportunities that are evolving in connection with the development of modern telecommunications and information technology. Still, companies are often unclear as to which PR tools they should really invest in so that their impact on the public is effective. Our research seeks to help companies orient themselves in the efficiency and use of various PR tools. Although it was aimed specifically at companies in the chemical industry, we believe that the results could be similar for other industries. However, this should be verified by further follow-up research.

Our hypothesis $\mathrm{H} 1$ has only been partially confirmed. Although some traditional PR tools are really widely used by companies and if they are not in the online environment (such as the company's website), they are also ineffective, according to respondents - see annual reports, corporate newspapers and magazines and occasional publications - but there are also PR tools from this category, which are insufficiently effective from the respondents' point of view, but companies do not use them much with the public either (identity media, bulletins, newsletters, press conferences). In general, it can be stated that traditional PR tools need to be carefully considered for their effectiveness and companies should try to implement modern technologies and trends in order to increase their effectiveness with the public. As 
confirmed by a number of studies, such as Allagui and Breslow (2016), digital tools and platforms are playing an increasingly important role in supporting PR efforts to reach the public. Nevertheless, the use of technology can never replace the creative implementation of a PR strategy and the production of effective content (Wolf \& Archer, 2018).

We believe that Hypothesis $\mathrm{H} 2$ can undoubtedly be rejected. Almost all monitored types of PR events have fallen into the area of average use and perceived effectiveness with the public. Sponsorship of sporting events was even rated as highly used and effective. The only tool not used by businesses is sponsorship of political events as they do not consider it effective. However, the relatively frequent use of PR events confirmed by this research does not mean that these events are used effectively. For example, research by Pokumensah et al. (2018) suggests that the use of PR events is frequent within PR, but often not fully coordinated to meet the company's goals. In addition, managers' assumptions about the effectiveness of these actions may be erroneous. This is confirmed by a survey of Freita et al. (2020) on the effectiveness of esports sponsorship, claiming that all interviewed experts believed that esports sponsorship would positively affect the brand image of sponsors, but only one third of the interviewed fans admitted their brand perception had improved due to the sponsorship.

As regards Hypothesis $\mathrm{H} 3$, only one side of the assumption has been confirmed, namely that the implementation and presentation of these activities has a major (environmental, social and philanthropic activities of the company) or medium (economic responsibility) impact on the public. The fundamental role of environmentally responsible activities from the public's point of view is also confirmed by a study by IPSOS (IPSOS, 2020). Unfortunately, this modern PR tool has not been consistently used by companies so far. The statement applies both to companies operating in the Czech Republic and to companies operating in a number of other countries, especially developing countries (KPMG, 2020). It applies both to companies in non-controversial industries, such as TOP100 companies in the Czech Republic or Ukraine (Tetrevova et al., 2019), and to companies in controversial industries, such as chemical companies in the Czech Republic (Tetrevova, 2018a, 2018b), in Ukraine (Tetrevova et al., 2020) and Slovakia (Tetrevova, 2018c). The fact is, as confirmed by our research, that many companies carry out a number of socially responsible activities, but fail to communicate effectively about them in relation to the public (Tetrevova et al., 2020). This problem is particularly significant in the field of social and philanthropic activities (Tetrevova et al., 2019, 2020).

Hypothesis $\mathrm{H} 4$ has been clearly confirmed by our research. It has been proven that larger companies (over 250 employees) use 16 monitored PR tools to a greater extent than smaller companies. As regards the other monitored PR tools (9 PR tools), no statistically significant difference has been found depending on the size of companies. The preference for smaller communication activities in terms of marketing tools in small businesses is also confirmed by the research of Lizbetinova et al. (2019), who claim that there is a range of limitations in marketing communication activities of small enterprises resulting from restricted finances as well as from the fact that owners and employees of small enterprises tend to be generalists rather than specialists, so their marketing expertise is often limited. The issue of the 
effectiveness of communication of CSR activities in small companies is addressed by Morsing and Spence (2019), who are inclined to believe that requiring extensive communication activities from small businesses is often inefficient.

Hypothesis $\mathrm{H} 5$ assumed that older and more experienced employees would have more confidence in more traditional PR tools. The senior managers' tendency to adhere to established traditional principles while trying to avoid unproven tools in communication is confirmed by Kusuma et al. (2020). But the assumption of Hypothesis H5 has been confirmed only with press releases. This often-used PR tool is viewed as more effective not only by senior managers (over 45 years old), but also by respondents from a higher level of business management.

Although the limitations of the research results are obvious - a relatively small number of respondents and focus only on the chemical industry - we believe that it has provided interesting insight into the issue and will allow companies to more efficiently allocate resources among the range of PR tools currently available to companies. In the future, it would certainly be interesting to monitor the usability and effectiveness of PR tools in relation to other stakeholders and to compare the results with other industries. Last but not least, it would be appropriate to find out whether managers' assumptions about the effectiveness of PR tools in relation to the public correspond to reality and to conduct a survey directly with the public.

Acknowledgments: In this section you can acknowledge any support given which is not covered by the author contribution. This may include administrative, technical, and foremostly financial support. Please add a grant title and number if applicable.

\section{References}

Allagui, I., \& Breslow, H. (2016). Social media for public relations: Lessons from four effective cases. Public Relations Review, 42(1), 20-30. https://doi.org/10.1016/j.pubrev.2015.12.001

Corbett, G. (2012, March). A Modern Definition of Public Relations. http://prdefinition.prsa.org/index.php/2012/03/01/new-definition-of-public-relations/

Destiny, A.O. (2018). Understanding the concept of publicity in Public relations: a synoptic review. Kuwait Chapter of the Arabian. Journal of Business and Management Review, 7(2), 32-34. https://doi.org/10.12816/0046066

Fawkes, A. G. J. (2019). A Global Capability Framework: Reframing Public Relations for a Changing World. Public Relations Review, 45, 101781. https://doi.org/ 10.1016/j.pubrev.2019.05.002

Foret, M. (2011). Marketing communication (in Czech) (3rd ed.). Computer Press.

Freitas, B. D. A., Contreras-Espinosa, R. S., \& Correia, P. A. P. (2020). Sponsoring Esports to Improve Brand Image. Scientific annals of economics and business, 67(4), 495-515. https://doi.org/10.47743/saeb-2020-0030

Ftorek, J. (2010). Public relations and politics: who and how manages our destinies with our consent (in Czech). Grada Publishing.

Garcia-Nieto, M. T., Vinaras-Abad, M., \& Cabezuelo-Lorenzo, F. (2020). Half a century in the evolution of the Concept of public relations (1970-2020). Review article. Profesional de la Informacion, 29(3). https://doi.org/10.3145/epi.2020.may.19

Hejlova, D. (2015). Public relations (in Czech). Grada Publishing.

Heskova, M., \& Starchon, P. (2009). Marketing communication and modern trends in marketing (in Czech). Oeconomica.

IPSOS. (2020, April 22). Corporate Social Responsibility: There Is Growing Pressure to Treat Employees Fairly. https://www.ipsos.com/cs-cz/spolecenska-odpovednost-firem-roste-tlak-na-ferove-chovani-k-zamestnancum

Jelinkova, M., Lostakova, H., \& Machackova, K. (2020). The Level of Use of Public Relations Tools and Evaluation of their Impact on the Reputation of Chemical Companies from the Perspective of the Czech 
Public. In Proceedings of 11th International Scientific Conference "Business and Management 2020". https://doi.org/10.3846/bm.2020.518

Kopecky, L. (2013). Public relations: history - theory - practice (in Czech). Grada Publishing.

Kotler, P., \& Keller, L. K. (2013). Marketing management (14th ed.). Grada Publishing.

Kotler, P., Armstrong, G., Harris, L. C. \& He, H. (2019). Principles of marketing (8th ed.). Pearson Education Limited.

KPMG (2020, December). The Time Has Come. The KPMG Survey of Sustainability Reporting 2020. https://assets.kpmg/content/dam/kpmg/xx/pdf/2020/11/the-time-has-come.pdf

Kusuma, H., Muafi, M., Aji, H. M., \& Pamungkas, S. (2020). Information and Communication Technology Adoption in Small- and Medium-Sized Enterprises: Demographic Characteristics. Journal of Asian Finance Economics and Business, 7(10), 969-980. http://doi.org/10.13106/jafeb.2020.vol7.no10.969

Lizbetinova, L., Starchon, P., Lorincova, S., Weberova, D., \& Prusa, P. (2019) Application of Cluster Analysis in Marketing Communications in Small and Medium-Sized Enterprises: An Empirical Study in the Slovak Republic. Sustainability, 11(8), 2302. http://doi.org/10.3390/su11082302

Morsing, M., \& Spence, L. J. (2019). Corporate social responsibility (CSR) communication and small and medium sized enterprises: The governmentality dilemma of explicit and implicit CSR communication. Human relations, 72(12), 1920-1947. http://doi.org/10.1177/0018726718804306

Musil, M. (2005). Mass media and publicity (in Czech). Oeconomica.

Myers, C. (2016). What's the legal definition of PR? An analysis of commercial speech and public relations. Public Relations Review, 42(5), 821-831. https://doi.org/10.1016/j.pubrev.2016.10.005

Novotna, E., \& Musil, M. (2017). About PR - introduction to public relations (in Czech). Prague University of Economics and Business.

Pokumensah, J. B., Marfowaa, M. O., Bonsu, T. T., \& Dankwa, A. (2018). Use of Public Relations Events as Strategic Marketing Tool. Journal of Applied Sciences, Arts and Theology, 2, 49-55. http://hdl.handle.net/123456789/525

Rubtcova, M., \& Pavenkov, O. (2019). PR-Tools and Youth Policy in Political and Socio-Economic Situation in Russia. IRAJ-International Conference on Humanities, Social Science and Business Management (ICHSSBM)), 2019. Available from https://ssrn.com/abstract=3317578

Solmonova, K. V., \& Volkonskij, Y. K. (2019). Image Formation as the Basic Subject of the Organization: PR Tools and Their Role in the Formation of a Positive Image. Комлуникология: электронный научньй журнал, 4(3), 7-15.

Sommerfeldt, E. J., Yang, A., \& Taylor, M. (2019). Public Relations Channel “Repertoires”: Exploring Patterns of Channel Use in Practice. Public Relations Review, 45, 101796. https://doi.org/10.1016/j.pubrev.2019.101796

Svoboda, V. (2009). Public relations: modern and efficient (in Czech) (2nd ed.). Grada Publishing.

Tetrevova, L. (2017). Communication of socially responsible activities by sugar-producing companies. Listy cukrovarnické a řepařské, 133(12), 394-396.

Tetrevova, L. (2018a). Communicating CSR in high profile industries: Case study of Czech chemical industry. Inzinerine Ekonomika-Engineering Economics, 29(4), 478-487. https://doi.org/10.5755/j01.ee.29.4.19199

Tetrevova, L. (2018b). Communicating socially responsible activities of chemical companies in the Czech Republic. Chemické listy, 112(2), 122-127.

Tetrevova, L. (2018c). Corporate social responsibility of chemical companies in Slovakia. Przemysl Chemiczny, 97(12), 2120-2123. https://doi.org/10.15199/62.2018.12.21

Tetrevova, L., Patak, M., \& Kyrylenko, I. (2019). Web-based CSR communication in post-communist countries. Applied Economics Letters, 26(10), 866-871. https://doi.org/10.1080/13504851.2018.1508866

Tetrevova, L., Patak, M., \& Kyrylenko, I. (2020). CSR web communication in controversial industries: The example of chemical companies based in post-communist countries. Journal of Promotion Management, 1-23. https://doi.org/10.1080/10496491.2020.1851849

Wolf, K., \& Archer, C. (2018). Public relations at the crossroads: The need to reclaim core public relations competencies in digital communication. Journal of Communication Management, 22(4), 494-509. http://doi.org/10.1108/JCOM-08-2018-0080 